\title{
Calcium soap from palm fatty acid distillate (PFAD) for ruminant feed: quality of calcium source
}

\author{
Lienda A. Handojo ${ }^{1, *}$, Antonius Indarto ${ }^{1}$, Dian Shofinita ${ }^{1}$, Anggina Meitha ${ }^{1}$, Rakhmawati Nabila ${ }^{1}$, and Harry Triharyogi ${ }^{1}$ \\ ${ }^{1}$ Department of Chemical Engineering, Faculty of Industrial Technology, Institut Teknologi Bandung, Bandung, Indonesia
}

\begin{abstract}
Calcium soap is potentially used as fat supplements for ruminants since it contains high concentration of fat and calcium that are useful for ruminants. The consumption of calcium soap may increase the yield and the fat content of milk, as well as increase the ruminant's fertility. Calcium soap can be produced from palm fatty acid distillate (PFAD), which is a byproduct of crude palm oil (CPO) refining process, and calcium oxide $(\mathrm{CaO})$. In this study, the effect of $\mathrm{CaO}$ quality on the acid value of the product has been observed. It was found that the reaction with lower concentration of active calcium of $\mathrm{CaO}$ resulted in products with a higher acid value, which indicates a lower reaction conversion. Thus, the produced calcium soap requires further treatment in order to remove the unreacted calcium and free fatty acid. Washing with hexane followed by either vacuum or convection drying has been found to be able to reduce the acid value of the product significantly.
\end{abstract}

\section{Introduction}

Calcium soap can be used as supplement for ruminants since it contains high concentrations of fat and calcium that are useful for ruminants. The calcium soap gives benefits for ruminants, particularly regarding the milk productivity and fertility increase. Calcium soap is produced from the reaction between fatty acid and calcium source.

Previous study reported that it was preferable to use the naturally source of fatty acids as raw material to produce calcium soap, such as beef or mutton tallow, palm oil, or lard [1]. Palm fatty acid distillate (PFAD) can be potentially used as raw material for the production of calcium soap since the fat content in PFAD can reach $81.7 \%$ [2]. Usage of PFAD with $87.1 \%$ free fatty acid content for calcium soap production has been reported [3]. Furthermore, PFAD is a by-product from crude palm oil (CPO) refining process, therefore the utilization of PFAD may add cost benefit for the industry. The product of CPO refining process usually consists of 5\% PFAD and 95\% refined, bleached, and deodorized (RBD) palm oil [4]. Considering that Indonesia is the largest producer of palm oil with a contribution of approximately $54 \%$ to the world total palm oil production in 2016 [5], the study regarding the utilization of PFAD will be interesting.

There are several calcium sources that can be used as raw materials for the calcium soap production. A previous study compared the possibility of using $\mathrm{Ca}(\mathrm{OH})_{2}$ and $\mathrm{CaO}$ as calcium sources, and concluded that the use of $\mathrm{CaO}$ resulted in a higher reaction conversion [6]. However, the quality of $\mathrm{CaO}$ produced from several sources in Indonesia may vary. The production of $\mathrm{CaO}$ depends on the effectivity of the $\mathrm{CaCO}_{3}$ combustion, on the condition during transport and storage since $\mathrm{CaO}$ is hygroscopic. This study discusses the effect of $\mathrm{CaO}$ quality on the acid value of the product, which reflects the reaction conversion. In addition, possible additional treatments, such as washing and drying, to decrease acid value of the product after reaction have also been explored.

\section{Methods of research}

\subsection{Materials}

Materials used in this study were $\mathrm{CaO}$ (Stone Garden and Padalarang Company) and PFAD (PT Tunas Baru Lampung Tbk).

\subsection{Methodology}

\subsubsection{Actual $\mathrm{CaO}$ determination}

Calcium oxide used was obtained from the ignition of quick lime as calcium carbonate. The actual amount of $\mathrm{CaO}$ should be determined by dissolving it in sucrose solution from ASTM rapid sugar test. The solution of calcium oxide was boiled and cooled at room temperature, then it was added $50 \%$ sucrose solution and

\footnotetext{
Corresponding author: lienda@che.itb.ac.id
} 
shaken for 30 minutes. Water was added until $250 \mathrm{~mL}$ mark in erlenmeyer was reached and filtered through whattman paper no. 1, discharging the first $15-30 \mathrm{~mL}$. Then sulfuric acid titrated the solution. The available lime was calculated as 4 times the volume of $0.357 \mathrm{~N}$ sulfuric acid [7].

\subsubsection{Saponification reaction}

The saponification reaction was carried out using modified reaction method followed by washing and drying process as shown in Fig. 1.

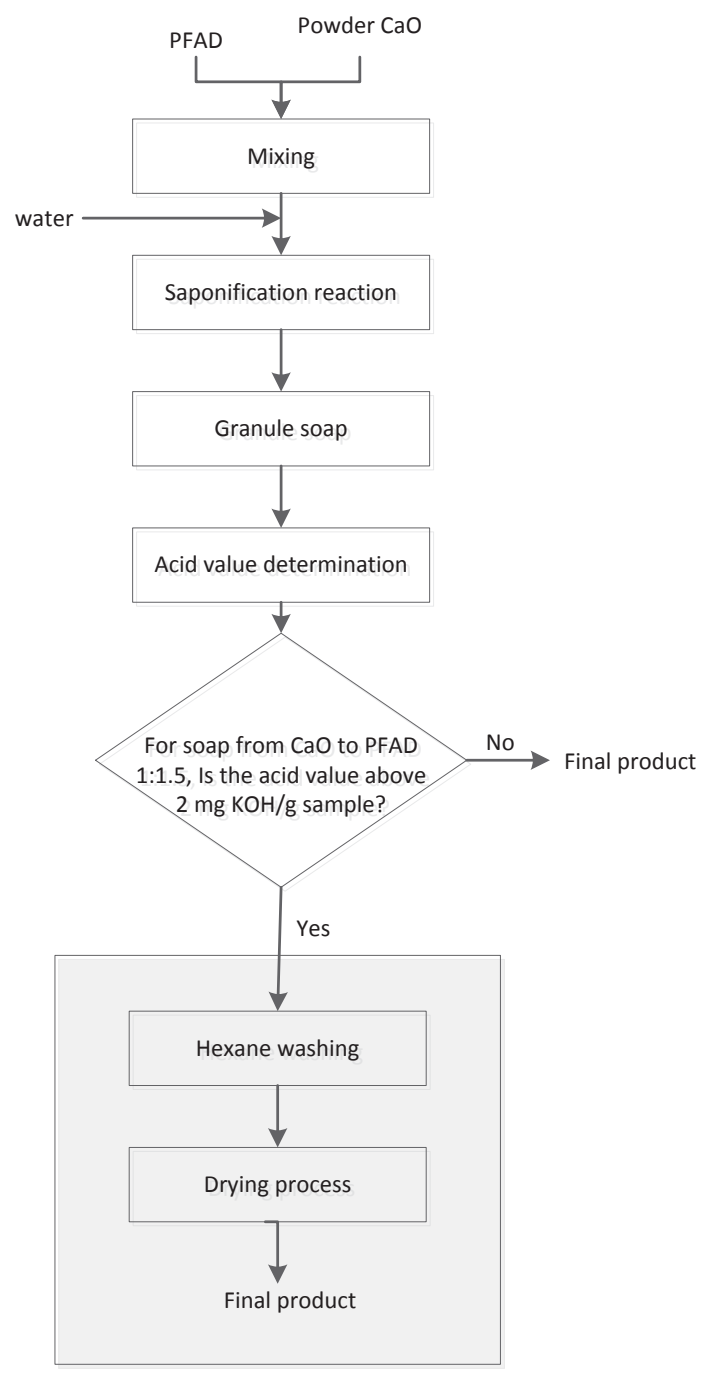

Fig. 1. Block flow diagram of the experiment methodology

The method was chosen since it needs less time for the reaction [8]. In this study, the stoichiometric mole ratio of $\mathrm{CaO}$ to PFAD was varied from 1 to 2 , the initial temperature of PFAD in the process was $60^{\circ} \mathrm{C}$, and percentage of mass of water was about $20 \%$ of PFAD. The mixture of molten PFAD and $\mathrm{CaO}$ was heated and stirred homogenously. Saponification reaction took place immediately after a certain amount of $60^{\circ} \mathrm{C}$ hot water was added and stirred for less than 10 minutes, during which the granule soap formed. The soap was relatively dry since the water evaporated as the mixture temperature raised due to the exothermic process of saponification.

\subsubsection{Washing and drying process}

Since the ruminants requires limited fatty acid content in their feed, the washing process was conducted to remove residual fatty acid present in calcium soap. The washing process was carried out by mixing nonpolar solvent, hexane, and product with ratio $3: 1$ and stirred it at $60^{\circ} \mathrm{C}$ for 30 minutes. The calcium soap filtrate obtained was dried in vacuum oven at $40^{\circ} \mathrm{C}, 0.4 \mathrm{~atm}$ and another was dried under convection dryer at $50^{\circ} \mathrm{C}$ for $3-4$ hours.

\subsubsection{Acid value determination}

Acid value was determined by ISO 660: 1990. One gram of calcium soap sample was taken and dissolved in ethanol, the mixture was then heated for 10 minutes. The solution was titrated by $0.01 \mathrm{~N}$ potassium hydroxide using phenolphthalein indicator [9].

\section{Results and analysis}

\subsection{The effect of $\mathrm{CaO}$ quality on acid value of the products}

Two different sources of $\mathrm{CaO}$ were used in this experiment. Based on the $\mathrm{CaO}$ analysis the result showed that the $\mathrm{CaO}$ content was about $40 \%(\mathrm{CaO} 1)$ and $75 \%(\mathrm{CaO} 2)$. The $\mathrm{CaO}$ production process has a significant influence on the quality of $\mathrm{CaO}$ produced. Some factors affecting the quality of $\mathrm{CaO}$ are the natural limestone, the calcination process, the method of storage, and the method of transport [10]. The quality of $\mathrm{CaO}$ which may vary due to source of production can be determined with titration method using sulfuric acid after $\mathrm{CaO}$ is dissolved in a solution of sucrose to calculate the amount of calcium in the form of oxide.

The quality of $\mathrm{CaO}$ used as the main raw material is essential and is directly proportional to the quality of the products. Figure 2 shows that the $\mathrm{CaO}$ content used had a very significant effect on product quality. The $\mathrm{CaO}$ quality in this research may be affected by the storage method that could convert the $\mathrm{CaO}$ to $\mathrm{Ca}(\mathrm{OH})_{2}$ due to moisture in the environment. The use of $\mathrm{Ca}(\mathrm{OH})_{2}$ for making calcium soap had lower quality than the product using $\mathrm{CaO}$ as calcium source [11]. Another strong factor was likely the presence of calcium carbonate in quicklime used regarding the incomplete combustion process.

A lower acid number was preferred and indicated a higher reaction conversion. In the stoichiometric mole ratio of $\mathrm{CaO}$ to $\mathrm{PFAD}$ of 1 , the $\mathrm{CaO} 1(40 \%)$ acid value was much higher than that of $\mathrm{CaO} 2(75 \%)$ which are 31.51 and $10 \mathrm{mg} \mathrm{KOH} / \mathrm{g}$ sample and are proportional to $14.35 \%$ and $4.5 \%$ fatty acids as palmitate, respectively. 


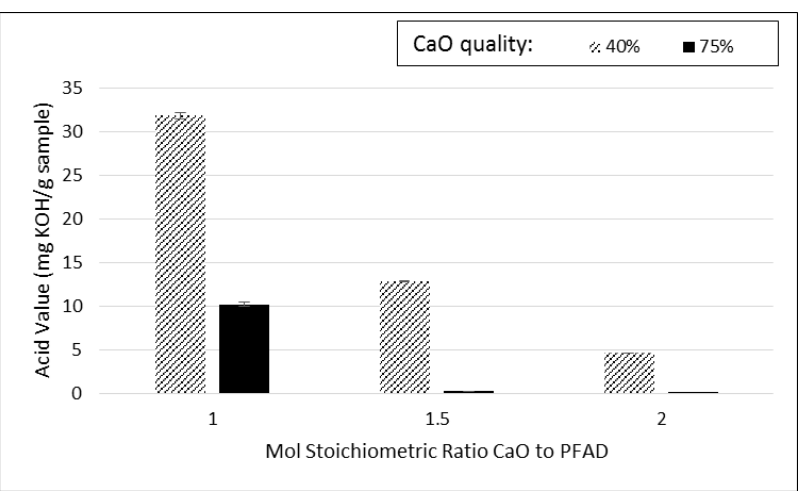

Fig. 2. The acid value of products vs. mol stoichiometric ratio at different $\mathrm{CaO}$ quality.

The higher the mole ratio of stoichiometry, the acid value will decrease. In the three variations of the $\mathrm{CaO}$ mole ratio, all the acid values of the product of $\mathrm{CaO} 1$ are still above 4 indicating the product was still below the commercial product standard. As for the product of $\mathrm{CaO} 2$, starting from the ratio of $\mathrm{CaO}$ to PFAD 1.5, the acid product number has been very low reaching 0.23 $\mathrm{mg} \mathrm{KOH} / \mathrm{g}$ sample. This value was already below to the free fatty acid content claimed by the commercial product [11].

\subsection{The effect of washing and drying process on Acid value of the products}

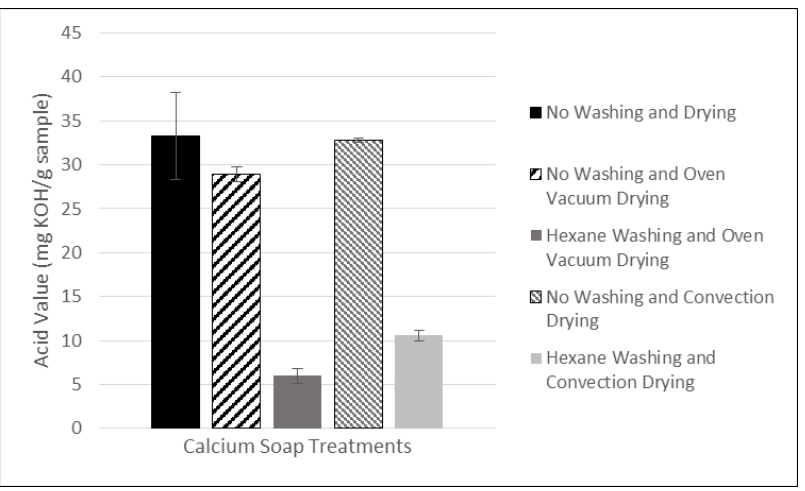

Fig. 3. The acid value of the products after washing and drying process.

The poor quality of $\mathrm{CaO}$ leads to a product which requires further processing to reach the desired quality. Figure 3 provides the effect of washing and drying process on the acid value of calcium soap. The soap was obtained from the reaction with a stoichiometric mole ratio of $\mathrm{CaO}$ to $\mathrm{PFAD}$ 1.5. The hexane wash treatment could reduce the acid value up to $68-82 \%$. The drying process was then necessary to remove hexane in the final product. Hexane was used to extract fatty acids or unsaponified material. Based on Akers and Peters (1984) the organic solvent used to extract the unsaponifiable matter is hydrocarbon with 4-14 $\mathrm{C}$ atoms in molecular compounds like hexane [12].

The high decrease in acid value was obtained from hexane washing followed by drying using a vacuum oven, which have an end product acid number of $6 \mathrm{mg}$ $\mathrm{KOH} / \mathrm{g}$, compared to hexane leaching and convection drying with an acid number of $10.6 \mathrm{mg} \mathrm{KOH} / \mathrm{g}$ sample. The convection drying could not remove hexane as good as vacuum oven drying. As a result, hexane left in the product which still carry some unreacted free fatty acid, increases the acid value. The drying process was carried out to remove the hexane from the final product. However, the final acid value was still higher than in the commercial products. Besides, the additional processes required more energy and additional materials, therefore it was relatively uneconomical.

\section{Conclusions}

$\mathrm{CaO}$ utilized as a raw material needs to be analyzed before reacted with fatty acids to produce calcium soap. Higher $\mathrm{CaO}$ content yields better calcium soap product which has lower acid value. The washing process followed by drying has an effect on the quality improvement of calcium soap products. The high quality $\mathrm{CaO}$ still has a greater effect on the product, compared to the additional treatment applied to the product resulted from low quality $\mathrm{CaO}$.

The authors would like to extend their sincere gratitude to BPDPKS Indonesia for providing the research grant and PT Tunas Baru Lampung Tbk for providing PFAD for this research.

\section{References}

1. McAskie, W., 1989. Ruminant Feedstuff, their production and apparatus for use therein. US Patent 48532333.

2. A.G.M. Top, Production and Utilization of Palm Fatty Acid Distillate, DOI10.1002/lite.200900070, (2010)

3. L. Handojo, A. Indarto, D. Shofinita, A. Meitha, R. Nabila, H. Triharyogi, Calcium Soap from Palm Fatty Acid Distillate for Ruminant Feed: Reaction Method. JEAS (2017)

4. Zero and Rainforest Foundation Norway, Palm Fatty Acid Distillate (PFAD) in Biofuels, (2016)

5. US Department of Agriculture, Oilseeds: world markets and trade. Foreign Agricultural Service, United State, (2016)

6. L. Handojo, A. Indarto, D. Shofinita, A. Meitha, R. Nabila, H. Triharyogi, J. Medwell ICABSE (2017)

7. W.E. Stone, F.C. Scheuch, A Method for Determining Calcium Oxide in Quicklime, JACS XVI 11 (1894)

8. L.F. Scott, M. Monrovia, H.D. Strachan, E. Monte, C.M. McCloskey, A. Altadena, C. Calif, Manufacture of Metallic Soap, US Patent 3803188 (1974)

9. FSSAI, Manual of Methods of Analysis of Foods Oils and Fats (2012)

10. M. Hassibi, Factors affecting the Quality of Quicklime (CaO) from Mining to Manufacturing Usage. Chemco System L.P. (2015) 
11. L. Handojo, A. Indarto, D. Shofinita, A. Meitha, R.

Nabila, H. Triharyogi, J. IJCAET 287 (2017)

12. J.B. Akers, D.C. Peters, , EP 0015116 B1 (1984) 